\title{
WHAT EDUCATIONAL DEVELOPERS NEED TO KNOW ABOUT FACULTY-ARTISTS IN THE ACADEMY
}

\author{
Natasha Haugnes \\ Academy of Art University \\ Hoag Holmgren \\ Professional and Organizational Development Network in \\ Higher Education \\ Martin Springborg \\ Minnesota State Colleges and Universities
}

Both educational developers and faculty-artists share the same goal: significant learning. Yet effective dialogue and collaboration between the two can be undermined without the educational developer's knowledge of signature pedagogies and discipline-specific terminology in the various disciplines of art. We examine several assumptions about artists and how these assumptions can be overcome for the benefit of educational developers, faculty-artists, and students. To this end, we provide suggestions for generating dialogue about teaching and learning with faculty-artists and for making these dialogues fruitful. 
The work of faculty who teach art in the academy (for example, theater and dance, fine arts, creative writing, music) is often misunderstood by nonartist educational developers. As a result, educational developers are less likely to learn about the signature pedagogies of various artistic disciplines, as defined by Shulman (2005), and are less likely to be able to deeply or broadly support faculty-artists in their teaching and scholarship. This misunderstanding is reflected in, if not influenced by, the promulgation of artist stereotypes in popular culture. In most films, for example, artists are portrayed as self-absorbed, mentally unstable, morally suspect, and highly skeptical of institutions, the academy most of all. Such stereotypes extend to the work faculty-artists do in the classroom. We might be tempted to believe such work is unplanned and undisciplined, privileging intuition over reason (and is thus immune to assessment or evaluation and so not to be taken seriously).

In the film Barfly (1987), Mickey Rourke plays a poet named Henry Chinasky, based on real-life poet Charles Bukowski, who lives in squalor and spends most of his time drinking, fighting, and writing. The film Pollock (2000) depicts the painter Jackson Pollock as essentially tortured, alcoholic, and self-destructive. Amadeus (1984) portrays Mozart as a rebellious savant with wild mood swings whose dedication to his work led to exhaustion and an early death. Many other popular films about art and artists highlight or exaggerate the darker realms of the artist's psyche-to name just a few, Black Swan (2010), Basquiat (1996), Frida (2002), Vincent and Theo (1990), The Rose (1979), The Shining (1980), Art School Confidential (2006), American Splendor (2003), The Piano Teacher (2001), Wonder Boys (2000), Crumb (1994), and Camille Claudel (1988). While many of these films feature accurate biographical events, it is also true that stories about stable, sober, and successful artists do not necessarily make popular movies, with Rivers and Tides (2001) being a notable exception.

Within the "unruly artist" family of films, a subcategory further highlights the artist's rebellious spirit by placing him or her in an academic setting, populated by stiff, rule-bound "academics," determined to force the artist to conform to the academic mold, and seemingly determined to destroy the artist's spirit. School of Rock (2003) and Mona Lisa Smile (2003) fit this pattern. In Mona Lisa Smile, the exceedingly uptight academic administrators admonish a new faculty-artist to "submit all lesson plans for approval and revision at the beginning of each semester," after learning that the newly hired artist teacher was exposing Wellesley University women of the 1950s to Jackson Pollock's nonconformist artwork. 
None of these films offers particularly admirable examples of facultyartists, administrators, or students. But the simplified characters and situations highlight a very real conflict: the struggle of artists to hold on to their passion in an academic setting and the struggle of the academy to understand and integrate artists into the scholarly context. While the focus of this chapter is what educational developers can learn about real faculty-artists and their world in order to support them in their teaching and scholarship, educational developers may note that "academics" in the film examples do not come out looking so great either. We hope that the following information may help to open conversations and mitigate unhelpful expectations that both parties may bring to the educational development table.

\section{Artist Traits}

We have found a family of traits that tend to set faculty-artists apart from their peers in other departments, although they are not as extreme as the cinematic depictions of artists. The point of sharing this list of traits is not to show how "special" artists are (indeed, any discipline could publish such a list), but rather to reveal opportunities for educational developers to begin dialogue and collaboration.

\section{Artists Are Risk Takers}

To create is to take risks. As a result, artists must be able to accept risk and mitigate fear. "If you don't create an atmosphere in which risk can be easily taken, in which weird ideas can be floated, then it's likely you're going to be producing work that will look derivative," says Pixar University dean Randy Nelson (Hempel, 2003).

Tip: Ask how faculty-artists get students to take creative risks in the classroom. Ask for input in planning a workshop or panel discussion on creativity.

\section{Artists Are Intrinsically and Tirelessly Curious}

Martha Breen, a faculty-artist member at the Academy of Art University, defines an artist as a person who has a vision and will do anything he or she has to-or learn anything necessary-in order to realize that vision. Judy Chicago studied pyrotechnics in order to realize her vision for her Multi-Colored Atmosphere series, essentially sculptural performance art 
with fireworks. Christo, for every temporary installation he creates, files a mountain of bureaucratic permits and environmental impact reports that would certainly discourage a person with less vision. Many ceramicists become experts in chemistry in their pursuit of specific textures and colors in glazes. An artist will never say, "That's not part of my job," when pursuing an artistic goal. Artists will not be deterred by permit processes, or lack of skills in a field.

Tip: Be curious. Attend departmental readings, openings, and performances. Introduce yourself; ask about the pockets of knowledge outside art that faculty-artists have acquired along the way. Ask about their work and their students' work.

\section{Artists Tend to See Holistically Rather Than in Parts}

Artists tend to see relationships, rather than differences, among seemingly unrelated elements. They look for underlying patterns that may not have been obvious to all of the casual observers who have gone before them. This trait is highlighted by a study that found that when looking at paintings, nonartists tend to focus on the objects and the people in the paintings, while visual artists' eyes move all around the canvas (Vogt and Magnussen, 2007). The artists are presumably seeing patterns in light and color or composition in the whole canvas. They are seeing the background as much as they are the objects and figures.

Tip: Ask faculty-artists if they have suggestions for how art-related resources, content, or teaching methods might be useful to faculty in the sciences, social sciences, or other disciplines. Solicit their ideas for a workshop, article, blog, or tweet on this topic.

\section{Artists Embrace Ambiguity}

Artists tend to thrive in the qualitative arena more than in the linear, logical arena. They embrace ambiguity and nuance instead of attempting to explain it away. The nineteenth-century poet John Keats, in talking about Shakespeare, called this quality negative capability: "That is when a man is capable of being in uncertainties, Mysteries, doubts, without any irritable reaching after fact \& reason" (Heath, 1973, p. 1105). Creative writing teacher Allyson Ritger brings this trait to the foreground by classifying her students in terms of how clear their writing is and how attached they are to whether the audience gets their message: "If a student is very attached to whether an audience is getting their message and they are very clear or obvious with their message, then sometimes it is not so interesting to 
read" (Flanagan $\&$ Shaffner, 2007). This analysis helps her to work with student writers within their own goals, although even she admits that in the academic context, coaching can be difficult if a student is unattached and unclear.

Tip: Ask to observe an instructor in the classroom in order to learn more about how art is taught. Art instructors are likely as interested in this topic as you.

\section{A Composite of Traits}

The list is not meant to imply that artists don't struggle with these traits personally or that the faculty-artists know how to nurture these qualities in their students. Faculty-artists, like postsecondary teachers everywhere, usually have little more than an "apprenticeship of observation" (Shulman, p. 57) by way of teacher training. That is, the only training they have, powerful as it may be, is from watching their own teachers teach in their many years of schooling; they tend to teach the way they were taught.

These traits begin to suggest what makes the "artist-ness" of an artist. We believe that it is this family of traits that academic institutions are often unprepared to support, nurture, and learn from.

\section{You Say Tomato; I Say Tomahto}

The language that educational developers use when engaging facultyartists is crucial in establishing a trusting relationship where learning can occur on both sides. An anecdote helps illustrate this point.

Before meeting with external accreditors, the administrator-liaison of an arts and design university handed out translation cards to the facultyartists who would be involved. The cards said:

\section{Accreditors Say}

Assessment strategies

Program learning outcomes

Course learning outcomes

\section{We Say}

Critiques, rubrics, portfolios, reels, thesis projects

What students learn in your department

What students learn in your class

The meeting went more smoothly than anticipated. The faculty-artists were able to adapt readily to accreditor jargon, and the university earned its accreditation with positive reviews. The translation cards made it clear, in a good-humored way, that both administrators and artists are involved in similar practices while employing different terms. 
But while the simple replacement of assessment with critique in an educational developer's vocabulary is a good start to opening conversations with faculty-artists, the translation is inadequate. There is a place for the educational developer to instruct a faculty-artist in well-researched and established best practice, but it is equally important for the educational developer to let go of structures that he or she uses to make sense of classroom teaching and be open to the apparent ambiguity of an arts classroom. We must remember that a lot of these established best practices originated in the fields of geology, education, math, literature, and physics-not art. This is not to suggest that educational developers must use only disciplinespecific tactics, but that there is a lot to learn from arts faculty that has the potential to inform the work we do with faculty in other disciplines. Because faculty-artists' scholarly work is less likely to take the form of citable, published academic articles, there is scant research in the teaching and assessment of art in higher education. Therefore, we need to be willing to suspend preconceptions about what is best practice in the arts classroom since so few of the best practices for teaching and assessing art have been codified.

The following sections explore what signature pedagogies and signature scholarship in the arts look like, as well as how educational developers can work with faculty-artists once a connection is established.

\section{Assessment $=$ Critique?}

The critique is sacred to an arts education and assumes many forms as a signature pedagogy in the arts, from professional pitches for a commission, to creative writing workshops. It is not simply an oral assessment of a product. Ask an art teacher what the goal of her or his critique is, and precious few will say, "To deliver grades and clear feedback." While many faculty do use critiques to assess work, the critique is also an end in itself. An analysis of critique as a signature pedagogy indicates that "it is more accurate to think of each critique as a step on the path toward the more ambitious project of the students' development of mature artistic practice" (Klebsadel \& Kornetsky, 2009, p. 102).

That path to mature artistic practice involves nurturing many of the traits outlined in the previous section, and all in a very public learning environment. While much of twentieth-century academia saw students with blue books seated at every other seat so that they could not copy others' work during exams, the logistical requirements in an arts classroom would never allow that type of individual, secretive activity. Imagine a drawing classroom where students could not see others' newsprint sketch pads. 
Students' work and feedback in the critique are displayed for the entire class to experience.

Given this environment, the critique has to be about more than assessment. It should push students to work as hard as they can to achieve their vision but without paralyzing them with fear. It should engage students in conversations and teach them to think for themselves. It should encourage students to discover how others see their art. It should be about learning to graciously accept feedback and ultimately make their own choices.

An educational developer observing a traditional art critique through the assessment lens may be baffled at the seemingly open-ended, inconclusive discussion about a piece of art. The developer may be listening for the criteria and discussion about the piece, while the art teacher may be paying attention to the student-artist's process: his or her engagement, tenaciousness, willingness to take risks, or ability to incorporate feedback while maintaining ownership over the final piece.

An educational developer might also find herself observing what she perceives to be a very focused critique in an art class, perhaps with an extensive rubric or objective checklist to guide clear feedback. In the developer's excitement over clear objectives and feedback tools, she might miss the fact that this art teacher might not be nurturing the all-important artist traits listed above. A student in the video series Fostering Creativity in the Classroom voiced this sentiment well in her description of what had happened to her own artistic creative process prior to arriving in a particularly gifted faculty-artist's class: "I had been overly critiqued on my designs. It was just work now. It wasn't even fun anymore. It was like-gotta get stuff done" (Flanagan \& Shaffner, 2007).

Educational developers should be able to support teaching artists in both situations. To establish trust and gain some knowledge of the artistfaculty's intent, the developers need to ask the instructor questions and perhaps exhibit a few of the artist trait themselves: they need to be curious and comfortable with ambiguity. They need to ask the types of questions that serve them in any discipline in which they might be observing teachers-for example: "Tell me about your critiques." "What do you want students to walk away from your class with that they did not have before?"

Tips: Once this communication is established, there are a few ways educational developers may support faculty-artists in critiques. They may:

- Work with faculty-artists to develop assessment criteria or learning outcomes based on process if that is indeed the focus. 
Rubrics can include criteria such as "responsiveness to feedback" or "design process."

- Work with overly focused skill-based instructors to embed the skill teaching in bigger questions about art, or more authentic art projects that nurture the artistic problem-solving traits and intrinsic motivation so central to being an artist.

- Assist faculty-artists to be clear and supportive in feedback.

- Assist teachers in developing grading systems that foster risk taking while holding students accountable for skills mastery. We know that too much emphasis on grading will extinguish students' intrinsic motivation.

- Help set up peer critiques using principles of group work or cooperative learning (though we do not need to call it that). Guidelines for task-based group work or even a jigsaw can be used in a critique setting. One art and design school encourages faculty to experiment with role playing in critiques with a model called "your creative director is stopping in."

- Support faculty-artists in building accountability into their critiques. Faculty-artists often say that students who are not being critiqued should be "listening and learning from the other critiques." Educational developers can help the faculty check in on this learning by setting up a classroom assessment technique or other follow-up activity: summarizing the most common points made in a critique journal, taking critique notes for each other, or synthesizing the whole critique in at the end.

\section{Active Learning = Making Art}

New faculty often enter the academy thinking they need to "act like professors." Whether stemming from encounters with instructors in real life or in film, this tendency to try to overintellectualize one's field can drain the excitement out of any classroom. Faculty-artists are no exception to this tendency. Richard Swan's film Professor Dancealot (2009), a dramatization of the dance professor who teaches his craft solely in a traditional lecture format, provides a humorous case in point. Faculty-artists can forget that it is better to pique and nurture students' curiosity through handson learning experiences than to rely on the more conventionally accepted lecture format associated with academe. 
Educational developers can remind instructors that their natural inclinations to have students make art in the classroom is a traditionally effective way to teach. While it is rarely referred to as active learning, this practice is nonetheless a signature pedagogy in the arts.

Tip: Educational developers can help faculty-artists with scaffolding projects, breaking the "doing art" down into smaller chunks, so that students can be successful.

Tip: Developers can help instructors incorporate low-stakes projects into lessons. For example, allow time to play with a new tool or experiment with a new medium in order to discover its possibilities.

\section{Scholarship: Do Not Call It Scholarship}

Generally scholarship refers to faculty members' contributions to their fields-whether that is in the form of new published research in the physical and biological sciences, books or publication credits positing new viewpoints in the social sciences and humanities, or the exhibition of new work in the arts. Many similarities exist across disciplines in terms of scholarly activity, but while faculty in the social sciences and humanities are more prone to speak in terms of research and scholarship, often faculty in the arts are not.

A perception among artists is that good art cannot be produced within the confines of the academy and therefore falls outside the realm of scholarship as it is traditionally defined. While an astrophysicist may wish that she could dedicate all her time to research and not teach in the classroom at all, the artist wishes she could spend more time in the studio or in the theater. She may fear losing her creative outlets and thereby lessening her chances of making significant contributions to her field; in fact, a common belief among artists is that "lifelong adherence to institutions of higher learning ... puts the poet, daily, class-wise, office-wise, library-wise, before the dragons of respectability and caution" (Eshleman, 1989, p. 39). Similarly, Bayles and Orland (1993,pp. 79-80) describe the associations that artists have with academia: "Indeed, the thought of working in the art education system either as student or faculty may sound about as attractive as standing beneath a steady drizzle of dead cats." This is one reason that so many artists who work in the academy cast the net of inspiration far beyond the ivory towers. Indeed, the evidence of the facultyartist's scholarship may be absent altogether from the university setting. 


\section{Traditional Forms of Scholarship in the Arts}

As educational developers, we need to familiarize ourselves with examples of scholarship in the arts if we are to encourage faculty colleagues to incorporate their scholarly work into their teaching, disseminate their work within the institution, and, in the case of early-career faculty, document their scholarship for the purposes of promotion and tenure down the road.

Table 4.1 and the lists that follow can serve as an introductory taxonomy of scholarship within arts disciplines:

Table 4.1. A Taxonomy of Scholarship in the Arts.

Performances Publications Exhibits Commissioned Work

Creative writing

Music and

theater

Visual arts
$\mathrm{X}$

$\mathrm{X}$

$\mathrm{X}$

$\mathrm{X}$

$\mathrm{X}$

$\mathrm{X}$

$\mathrm{X}$

Creative Writing

o The publication of new poetry, fiction, nonfiction, and drama

o Readings or performances

o Editing, publishing, and distributing a literary journal (departmental or national)

o Editing an anthology

Music, Theater, and Dance

O Performances in which the faculty member has played a role

o Productions in which the faculty member has served in the role of director or writer

o Composition of music-either by the faculty member along or commissioned for a larger production or purpose

Visual and Fine Arts

O The creation and exhibition or dissemination of new work. Solo exhibitions are typically held in higher regard than participation in group exhibitions, although there may be exceptions to this depending the extent to which the show was collaborative. 
- Exhibitions in which the faculty member served as curator.

o Commissioned work for public exhibition, such as work that is incorporated into new building projects, or private collection.

Although these categories are by no means a comprehensive view of scholarly activity within all arts disciplines, they provide a foundation of understanding that can lead to productive conversations and consultations with faculty in the arts.

A good entry into discussions of scholarship with all faculty colleagues, regardless of discipline, is to get to know their work. In the arts, this means researching arts faculty members for evidence of the types of work listed. We can use the knowledge to assist faculty in framing their work as scholarship so as to gain the recognition they deserve from their institutions. We can also support faculty in seeing and enhancing connections between scholarship and teaching.

Tip: Begin conversations with faculty-artists about what precedes their scholarly activity in terms of research and work production. These don't show up in footnotes as they often do in other disciplines' scholarly publications.

Tip: Ask faculty-artists how they incorporate their own work or their colleagues' work in the classroom.

\section{Undergraduate Research}

One direction we might take conversations with faculty-artists is toward undergraduate research. This is an unfamiliar term to many arts faculty, which is perhaps the reason that many have not embraced undergraduate research as a way to bring together their creative and teaching lives. The barrier for many faculty members to bringing their research into the classroom as a teaching method is not being able to envision the positive impacts on student learning or on their own research.

The following is an example of how one of us (M.S.) describes doing this in a course. An educational developer could support this type of project in any number of disciplines:

Community Education was a photographic essay that I conducted as a faculty member at Inver Hills Community College in Inver Grove Heights, Minnesota. What preceded this project was an acknowledgment that in teaching four or five courses per semester, I had almost entirely lost sight of my own work. The lack of engagement in my 
work outside of the classroom was having a negative effect on my teaching. In short, I was losing my "spark" as an instructor.

I gave my students and myself an assignment: to document in photographs our lives and the lives of their peers outside the classroom doors. In doing this work, my students and I saw first-hand the many challenges facing our respective groups, and the result was the development of a mutual respect for our workloads as well as the many challenges we face in becoming model students and instructors.

By semester's end, I had gathered hundreds of student photographs on the multitude of issues facing them both in and out of the classroom. I had also established a considerable body of my own work on the topic of teaching at a community college. Students who participated in this project developed an interest in photography unlike I had experienced in other beginning photography students.

Tip: Help faculty conceptualize and design undergraduate research projects. Opportunities include mentorships or apprenticeships in the form of departmental publications, exhibits, and readings. Assist in incorporating these projects into course design, curriculum, and assessment methods.

\section{Going Meta: The Scholarship of (Arts) Teaching and Learning}

Embedded within the enterprise of the scholarship of teaching and learning (SoTL) is the dissemination of findings to colleagues for the betterment of those involved in the teaching and learning process-faculty and students alike. SoTL is central to the learning paradigm, as opposed to the instruction paradigm, as defined by Barr and Tagg (199.5). This vision is of "the institution itself as learner-over time, it continuously learns how to produce more learning with each graduating class, each entering student" (p. 14)."

Talk to any faculty-artist for long, and you're bound to arrive at some deep thinking about the practice of teaching in the arts. A number of common questions arise between colleagues at departmental meetings and during art conferences-for example:

"Can art be taught?"

"What is good art?"

"Should I grade for effort?"

"What is the role of talent?"

"Can skills be taught in the absence of creativity?" 
"How can instructors quantifiably measure students' growth as artists?"

"Do I have the right to judge my students' art?"

"How do I assess creativity?"

"Can I assess and nurture creativity simultaneously?"

Tip: Engage faculty-artists in conversations about teaching and learning within the arts. Tap into what they are already thinking about, and nudge them to formalize their interests into true SoTL research projects.

Tip: Host faculty learning community meetings to fertilize the seeds of SoTL projects within arts disciplines.

\section{Conclusion}

By opening conversations and strengthening ties with faculty-artists, educational developers not only support their artist colleagues in the areas of teaching and learning but also enrich their own understanding of effective teaching, learning, and scholarship. With creativity and initiative, this new understanding may ultimately be extended to support the enterprises of teaching and learning in disciplines beyond the arts: "We can learn a great deal by examining the signature pedagogies of a variety of professions and asking how they might improve teaching and learning in professions for which they are not now signatures" (Shulman, 2005, p. 58).

\section{REFERENCES}

Barr, R. B., \& Tagg, J. (1995, November/December). From teaching to learning: A new paradigm for undergraduate education. Change, 12-25.

Bayles, D., \& Orland, T. (1993). Art and fear: Observations on the perils (and rewards) of artmaking. Santa Cruz, CA: Image Continuum.

Eshleman, C. (1989). Novices: A study of poetic apprenticeship. Los Angeles, CA: Mercer \& Aitchison.

Flanagan, M., \& Shaffner, M. (Directors). (2007). Fostering creativity in the classroom. Retrieved from http://elixr.merlot.org/case-stories /understanding-meeting-students-needs/creativity/fostering-creativity2

Heath, W. (Ed.). (1973). Major British poets of the romantic period. New York, NY: Macmillan.

Hempel, J. (2003, June 4). Pixar university: Thinking outside the mouse. San Francisco Chronicle. Retrieved from http://articles.sfgate.com/ 
2003-06-04/bay-area/17493262_1_pixar-s-emeryville-technicaldirector-bill-polson-pixar-president-edwin-catmull/2

Klebsadel, H., \& Kornetsky, L. (2009). Critique as signature pedagogy in the arts. In R.A.R. Gurung, N. L. Chick, \& A. Haynie (Eds.). Exploring signature pedagogies: Approaches to teaching disciplinary habits of mind (pp. 99-117). Sterling, VA: Stylus.

Shulman, L. (2005). Signature pedagogies in the professions. Daedalus, 1.34(3), 52-59. Retrieved from http://search.proquest.com/docview/210573746? accountidv 27957

Swan, R. (2009, September). Professor Dancealot. Retrieved from http://www youtube.com/watch?vv1k8aeDUC9XQ

Vogt, S., \& Magnussen, S. (2007). Expertise in pictorial perception:

Eye-movement patterns and visual memory in artists and laymen.

Perception, 36(1), 91-100. 